\title{
SHOCK: MECHANISMS AND THERAPY ${ }^{*}$
}

\author{
Ronald H. Dietzman, M.D. $\nmid$ William G. Manax, M.D., $\neq$ and \\ Richard C. LILleheI, M.D., PH.D. $\$$
}

\section{INTRODUCTION}

Despite the lavish use of vasopressors and antibiotics, the mortality rate of septic and cardiogenic shock remains at 50 to 80 per cent. ${ }^{1}$ These disappointing results have caused us to investigate the basic mechanisms responsible for shock from these and other causes.

Shock is an elusive term, defying a uniformly acceptable definition, but a definition built around a deficiency in tissue blood flow satisfies most investigators. This deficit in regional blood flow is usually secondary to a decrease in cardiac output and an increase in peripheral resistance. A decrease in cardiac output results from either primary "pump" failure, as in cardiogenic shock, ${ }^{2}$ or a decrease in the effective circulating blood volume, as in haemorrhagic shock. ${ }^{3}$ With this fall in cardiac output, there is a compensatory rise in the peripheral resistance owing to baroreceptor activity. An increase in peripheral resistance may also result from the sympathomimetic effects of endotoxin of Gram-negative bacteria in septic shock ${ }^{4}$ or from an increase in blood viscosity, such as occurs in burns or pancreatitis.

\section{MEChaNisMS OF SHOCK}

There are four basic components of the circulatory system to be considered in shock: the heart, the blood vessels, the blood volume, and the blood viscosity. Alterations in function of any one component may lead to shock. This interrelated system is expressed by the formula pressure $=$ flow $\times$ resistance. Pressure, represented by blood pressure, is the dependent variable. Flow is related to both the cardiac output (the pumping ability of the heart) and the effective circulating blood volume (represented by the central venous pressure). Resistance (total peripheral resistance) is governed by the pre- and postcapillary arterioles. These arterioles are under the influence of vasoactive substances, but of primary importance is norepinephrine. Release of this potent vasoconstrictor at sympathetic nerve endings results in pre- and postcapillary arteriolar vasoconstriction in the cutaneous and visceral microcirculation and an increase in peripheral resistance in the affected area. Increases in the viscosity of the blood add to the resistance to flow in the microcirculation. ${ }^{5}$

- From the Department of Surgery, University of Minnesota Medical School, Minneapolis, Minnesota. Supported by U.S.P.H.S. Grant No. 02941, U.S. Army Medical Research and Development Command, Grant No. DA-49-193-MD2539, and a grant from the Minnesota Heart Asssociation.

†Sterling-Winthrop Institute Research Fellow.

tU.S.P.H.S. Postdoctoral Research Fellow.

Professor of Surgery. 


\section{Experimental SHock Models}

There are three principal types of shock which concern the clinician: haemorrhagic, cardiogenic, and septic. In haemorrhagic shock there is an absolute volume deficit, producing a decrease in venous return to the heart and a fall in cardiac output. This reduction in cardiac output stimulates the baroreceptors and leads to an increase in sympathetic nervous system activity. The resultant outpouring of norepinephrine causes vasoconstriction and a rise in peripheral resistance (Fig. 1).

\section{Haemorrhagic Shock}

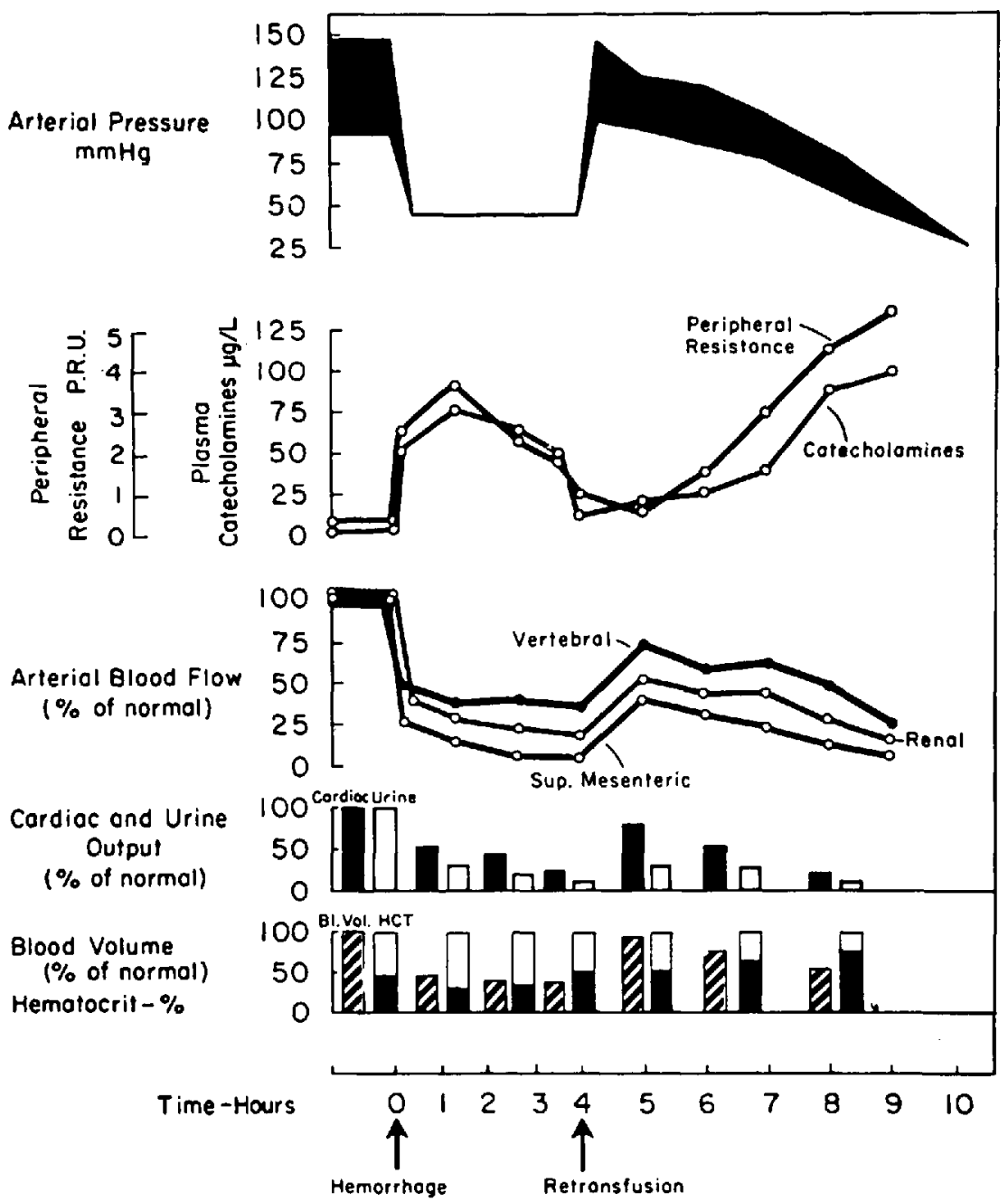

Figure 1. The haemodynamic response seen in experimental haemorrhagic shock in dogs. Note the rise in peripheral resistance parallels the rise in plasma catecholamine concentration. 
In cardiogenic shock which may follow acute myocardial infarction, openheart surgery, or chronic congestive failure, primary pump failure is the inciting factor for fall in cardiac output. This decrease again stimulates aortic and carotid baroreceptors, norepinephrine release, and an increase in peripheral resistance (Fig. 2).

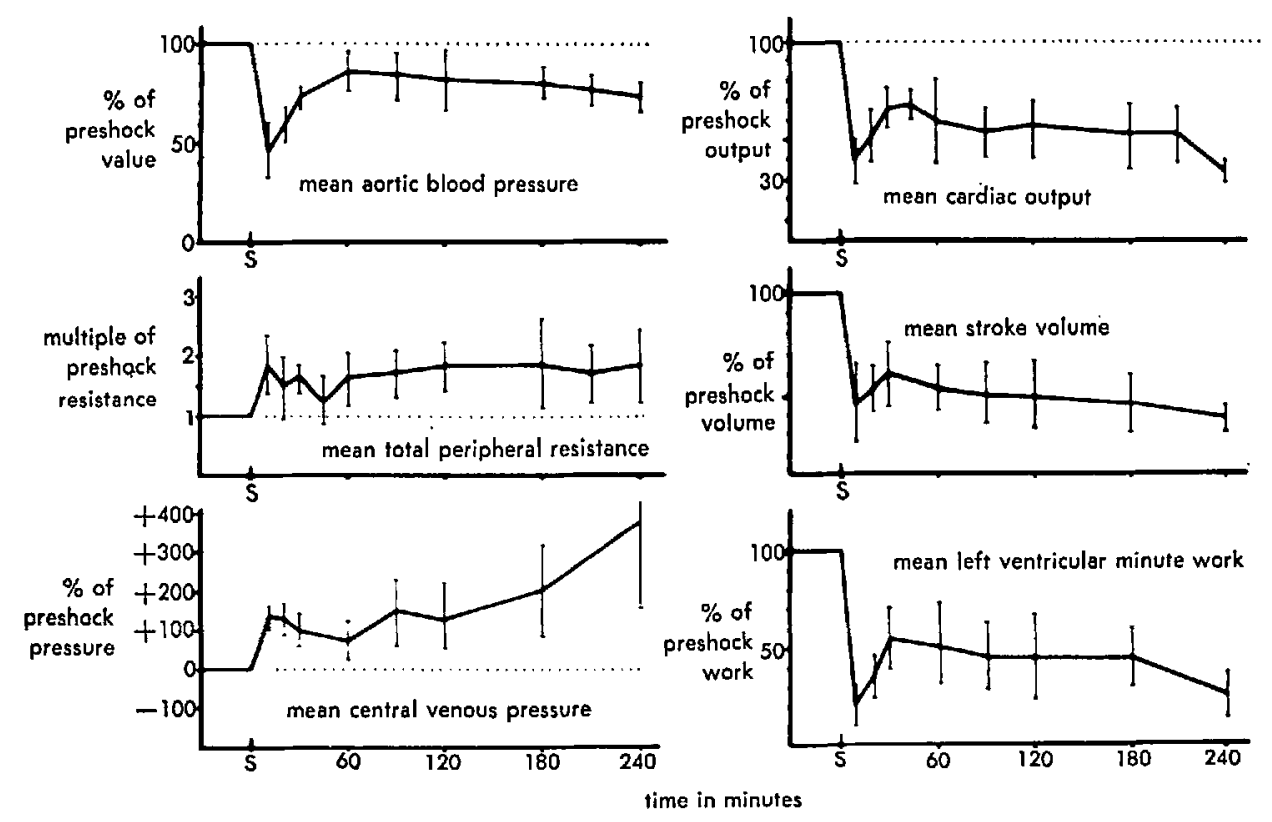

FIGURE 2. Haemodynamic changes in experimentally induced cardiogenic shock in dogs.

In septic shock, the endotoxins of Gram-negative bacteria themselves, as well as in combination with a heat-labile factor in the serum, are sympathomimetic and cause an increase in the circulating catecholamines, epinephrine and norepinephrine. This catecholamine elevation is mirrored by an increase in pheripheral resistance (Fig. 3). As shock progresses, there is a pooling of blood within the abdominal viscera of dogs, resulting in a marked reduction in the circulating blood volume and a fall in cardiac output. This fall in output causes additional stimulation to the sympathetic nervous system, again through baroreceptor activity.

In all three forms of shock in the dog, there is a decrease in the cardiac output and an increase in peripheral resistance, resulting in a significant decrease in regional blood flow to the viscera, as seen by the reduction in intestinal, hepatic and renal blood flow (this is associated with a decrease in urinary output). The brain and the heart, whose circulations are essentially insensitive to the vasoactive substances, are preferentially spared from increases in resistance and consequently receive a larger share of the cardiac output.

Therapy in each of these three types of shock in dogs, when directed toward blocking this pernicious sympathetic effect while maintaining an effective 


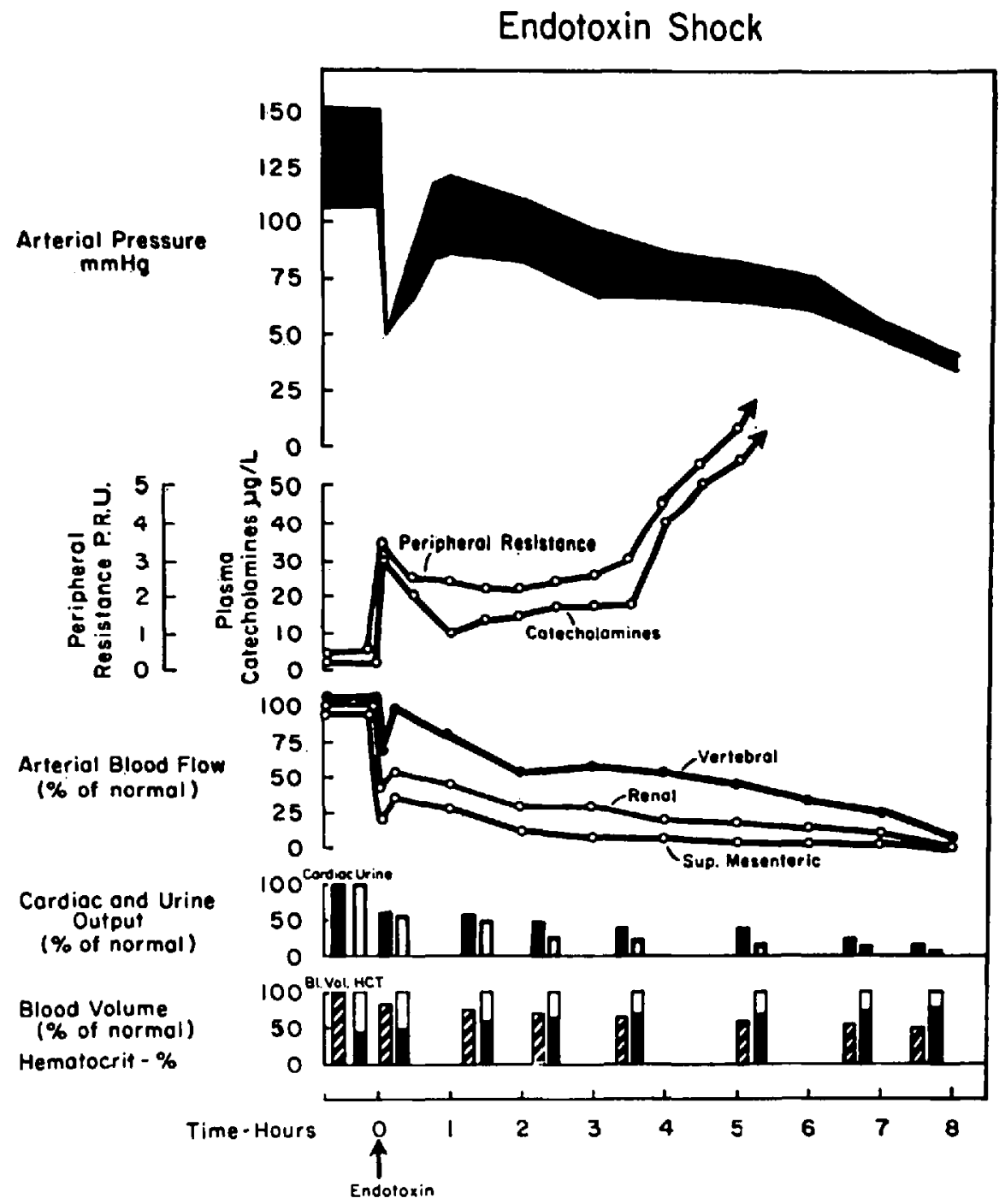

FIGUite 3. Haemodynamic responses in experimental endotoxin shock in dogs. Note the rise in peripheral resistance parallels the rise in plasma catecholamine levels.

circulating blood volume, results in the greatest increase in the survival rate. In contrast, therapy directed at augmenting the sympathetic effect already present does not significantly alter the survival rate (Table I). Those dogs receiving alphablocking (phenoxybenzamine) or beta-stimulating (isoproterenol) drugs or steroids had a significant decrease in mortality compared to those receiving alpha-stimulating (e.g., levarterenol) drugs. ${ }^{6}$

An alternate means of reducing sympathetic effect, other than by blocking drugs, is supersaturation of the sympathetic nervous system with epinephrine. Acute tolerance studies in dogs have shown that by supersaturation, produced 
TABLE I

Survival in Haemorrhagic, Endotoxin, and Cardiogenic Shock Treated with Vasopressors and Vasodilators

\begin{tabular}{lccc}
\hline \hline & No. of dogs & $\begin{array}{c}\text { No. of 72-hour } \\
\text { survivors }\end{array}$ & $\begin{array}{c}\text { Per cent } \\
\text { survival }\end{array}$ \\
\hline $\begin{array}{l}\text { Haemorrhagic shock } \\
\text { controls }\end{array}$ & 15 & 1 & 7 \\
$\quad \begin{array}{l}\text { Levarterenol } \\
\text { Phenoxybenzamine }\end{array}$ & 10 & 0 & 0 \\
Endotoxin shock & 10 & 8 & 80 \\
$\quad$ controls & 90 & 6 & 7 \\
$\quad$ Levarterenol & 10 & 0 & 0 \\
$\quad$ Phenoxybenzamine & 10 & 9 & 90 \\
Cardiogenic shock & & & \\
$\quad$ controls & 20 & 5 & 25 \\
Levarterenol & 11 & 1 & 9 \\
Phenoxybenzamine & 9 & 7 & 78 \\
\hline
\end{tabular}

by gradually increasing parenteral doses of epinephrine during a month's period, ${ }^{7}$ the sympathetic nervous system becomes unresponsive to stimulation. For example, a group of dogs were made tolerant to lethal doses of epinephrine. Usually lethal haemorrhagic, endotoxin, and cardiogenic shock were then induced in these tolerant dogs. The survival rate in each group (80\%) was significantly higher than in the control counterpart (20\%) (Table II). The haemodynamic response of tolerant dogs to shock is less intense than in normal dogs. This is reflected in a smaller increase of peripheral resistance and a greater cardiac output. Moreover, this decreased responsiveness of the microcirculation of the viscera in tolerant dogs ensures that these same areas receive a more equitable portion of the cardiac output. These factors are apparently responsible for the increased survival rate in tolerant dogs, whatever the original insult which precipitated the shock.

In summary, maintenance of an effective circulating blood volume and moderation of the sympathetic stimulation in shock is associated with a marked

TABLE II

INTERRELATIONShip betweEn SHock DUE to HaEmorRHage, ENDOTOXIN, and M yocardial INFarction in EpINEPhrine-Tolerant DogS

\begin{tabular}{lccc}
\hline Group & No. of dogs & $\begin{array}{c}\text { No. of 72-hour } \\
\text { survivors }\end{array}$ & $\begin{array}{c}\text { Per cent } \\
\text { survival }\end{array}$ \\
\hline $\begin{array}{l}\text { Haemorrhagic shock } \\
\text { "controls" }\end{array}$ & 41 & 2 & 5 \\
$\begin{array}{l}\text { Haemorrhagic shock in } \\
\text { epinephrine-tolerant dogs }\end{array}$ & 10 & 8 & 80 \\
$\begin{array}{l}\text { Endotoxin shock } \\
\text { "controls" }\end{array}$ & 90 & 6 & 7 \\
$\begin{array}{l}\text { Endotoxin shock in } \\
\text { epinephrine-tolerant dogs }\end{array}$ & 10 & 7 & 70 \\
$\begin{array}{l}\text { Cardiogenic shock } \\
\text { "controls" }\end{array}$ & 20 & 5 & 25 \\
$\begin{array}{l}\text { Cardiogenic shock in } \\
\text { epinephrine-tolerant dogs }\end{array}$ & 10 & 10 & 100 \\
\hline
\end{tabular}


improvement in the survival rate in dogs, however this is accomplished. This basic mechanism of shock is well documented in dogs, and it appears from preliminary studies that this same series of events occurs in man.

\section{Clinical Studies}

Detailed studies of shock in man are not as numerous as those in the dog, but centres for the study of shock are being set up in increasing numbers. To evaluate the mechanisms of shock in man at our own hospital, in addition to providing data used in planning and following therapy, we have established a "Mobile Clinical Shock Unit" (Fig. 4). This mobile unit is taken to the bedside of patients in shock wherever they are-emergency, operative, recovery, intensive care, or ward rooms. In addition to measurements of heart rate and intra-arterial blood

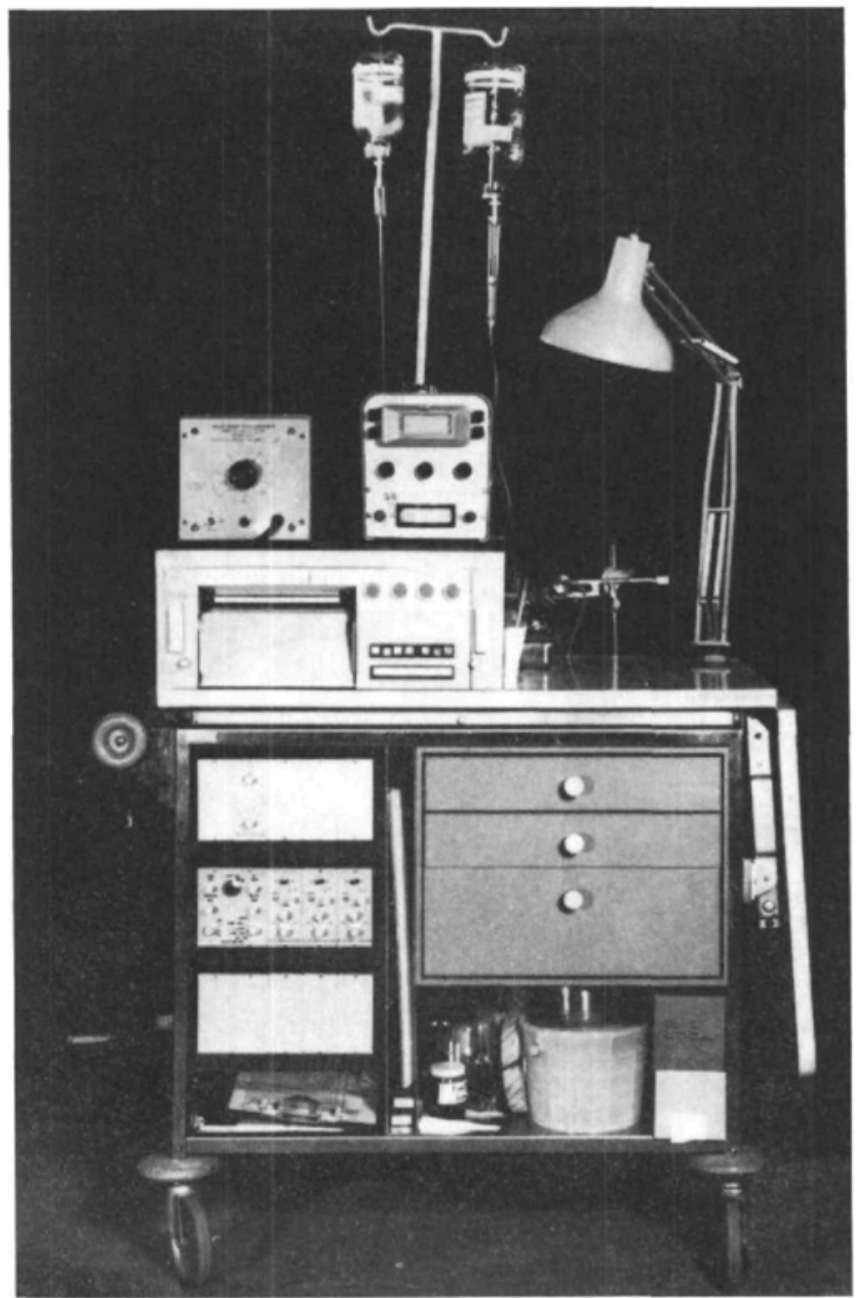

Figure 4. Mobile Clinical Shock Unit. 
pressure, measurements of central venous pressure, cardiac output, total peripheral resistance, and cardiac work are made. These determinations are available quickly and continuously, and are used to plan and follow therapy of patients in shock.

Representative patient data in each of the three forms of shock discussed above are shown in Figures 5, 6, and 7. In Figure 5, the primary problem is hypovolaemia. Although the blood pressure remained stable in the postoperative period, while the cardiac output and blood volume were reduced, its stability was attributed to the marked elevation in total peripheral resistance. This reduction in effective circulating blood volume is reflected by the decreased central venous pressure. The elevation of total peripheral resistance reflects generalized vasoconstriction, as evidenced by reduction in urinary output and the pale, cool extremities of the patient.

Figure 6 represents a patient in cardiogenic shock after mitral and tricuspid valve replacement. Postoperatively the patient suffered falling blood pressure, an

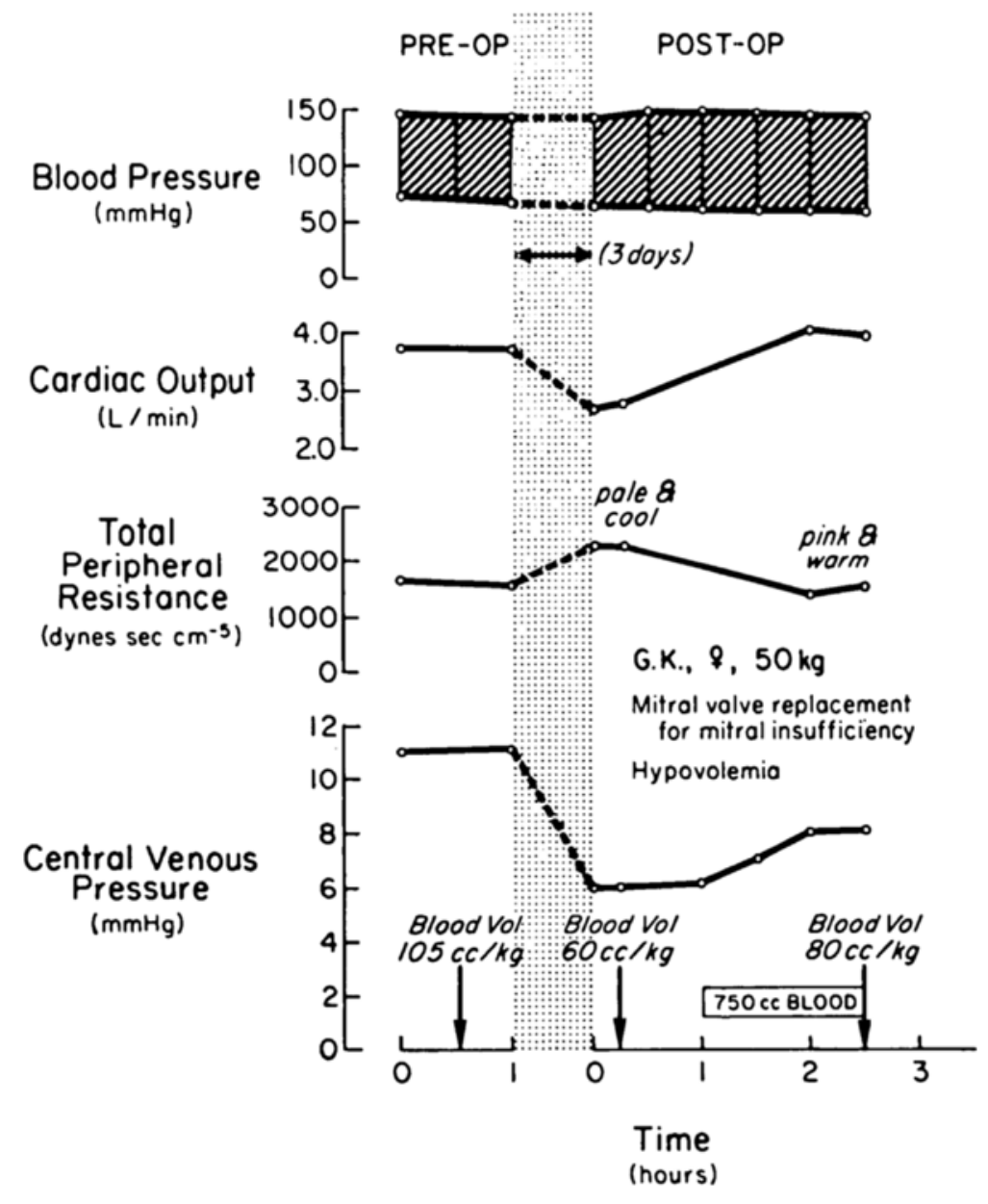

Figune 5. Haemorrhagic shock in man (for explanation of graphs, see text). 


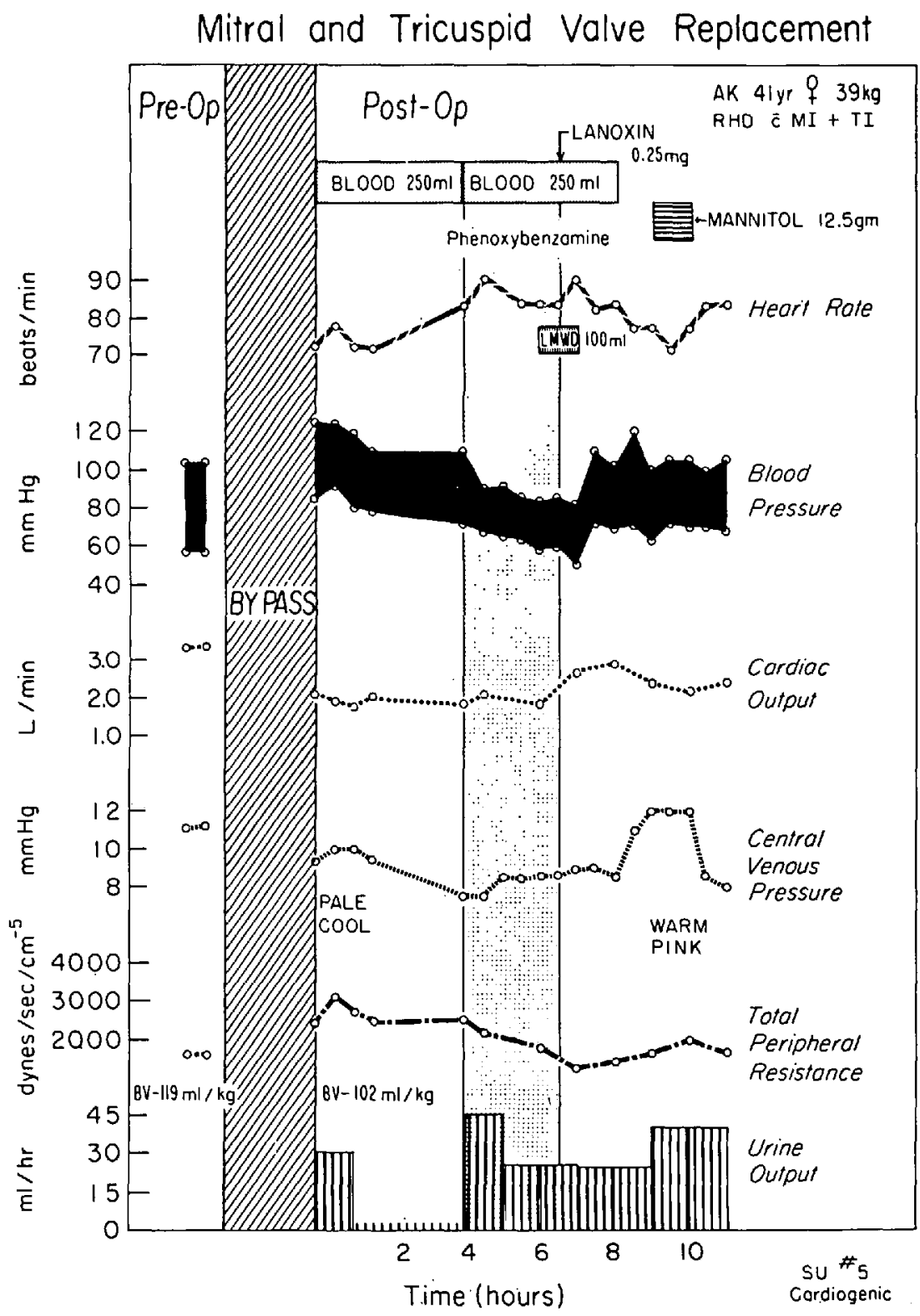

Figune 6. Cardiogenic shock in man (for explanation of graphs, see text).

elevated central venous pressure and blood volume, a reduced cardiac index, and a markedly elevated total peripheral resistance manifested by pale, cool extremities and a falling urinary output. Maintenance of the effective circulating blood volume and alpha-adrenergic blockade with phenoxybenzamine produced dramatic effects. The blood pressure and pulse pressure increased, as did the cardiac index, and the total peripheral resistance fell, reflected by the patient's pink, warm extremities and increased urinary output. 
Klebsiella Septicemia

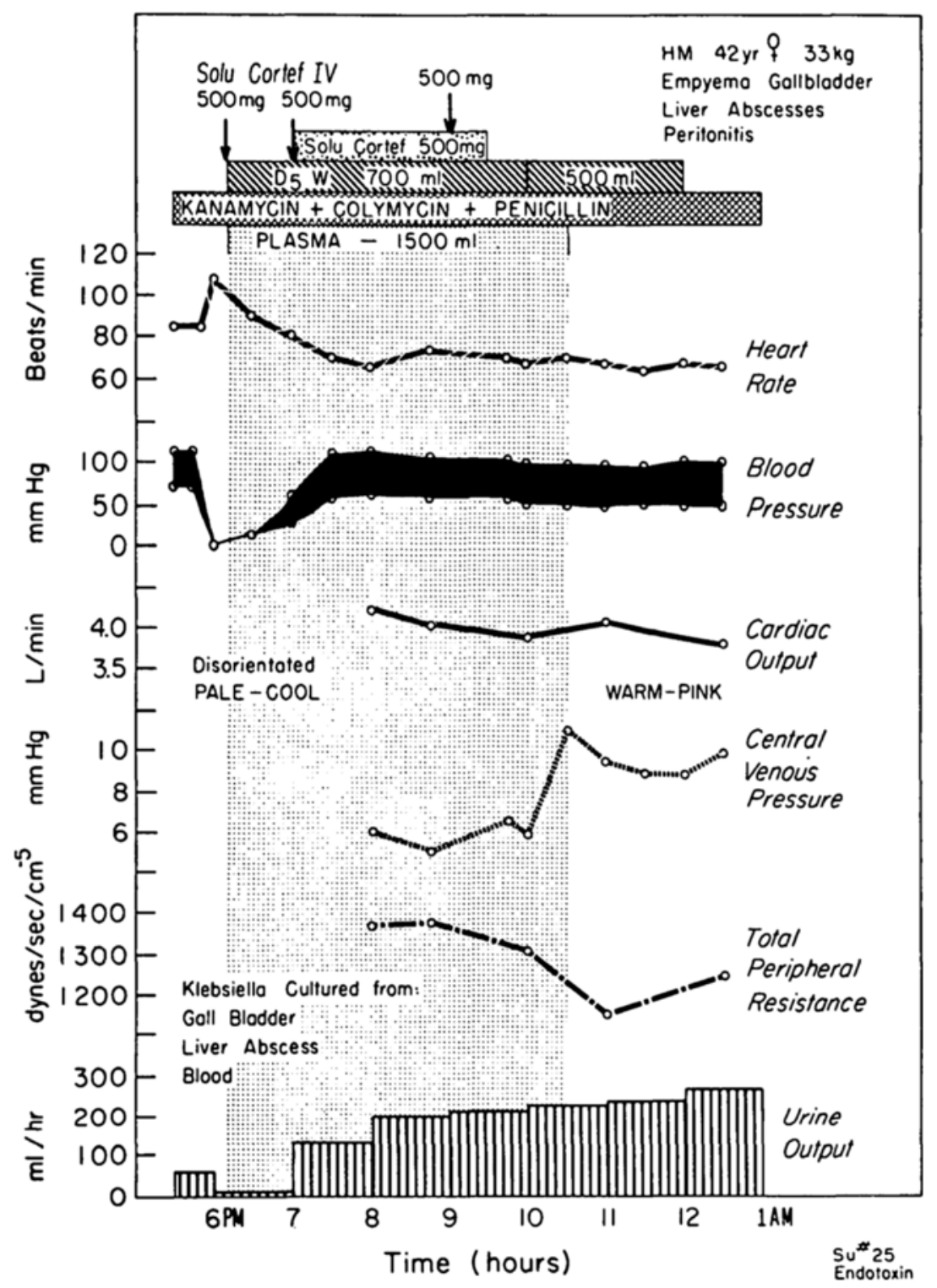

Figure 7. Endotoxin shock in man (for explanation of graphs, see text).

Septic shock due to Klebsiella is seen in Figure 7. The same clinical picture was present as in the two previous cases; however, the cardiac output and total peripheral resistance were within normal limits. In this patient, there was a shunting of blood through a markedly inflamed peritoneal cavity and, consequently, the calculated value for the total peripheral resistance was within the normal range. Yet the patient showed all the signs of decreased flow in the microcirculation of the skin and viscera, as manifested by pale, cool skin, oligaemia and acidosis, resulting from poor perfusion of these areas. Thus, the low resis- 
tance in the area of inflammation covers up the high resistance in the viscera and skin not involved in the infection. Restoration to a normal effective circulating blood volume and the administration of steroids (Solu-Cortef, $50 \mathrm{mg} . / \mathrm{kg}$.) in this patient resulted in a further decrease in the calculated value of total peripheral resistance and a decrease in regional resistance (warm, pink extremities and increased urinary output). It is well to remember that the microcirculation of the lung as one of the viscera is highly sensitive to vasoactive substances of all kinds. Along with the kidney it also appears to be the principal early target of endotoxin in man. This fact probably explains why tachypnoea and dyspnoea without evident cause are often harbingers of impending septic shock due to Gram-negative bacteria. The clinician must use this early sign as a signal to urgently seek and eliminate the cause of the infection. Only by early treatment of Gram-negative bacterial sepsis before shock occurs can we salvage more patients.

In each of these three cases, as we have seen in other cases of shock, there was a reduction in effective tissue blood flow and an increase in regional resistance. Restoration of an effective circulating blood volume, digitalization if indicated to improve the ionotropic action of the pump, and reduction of regional resistance (blockade of sympathetic overstimulation) have produced salutary results.

\section{SuMMARY}

A unitarian concept of shock has been proposed based upon theoretical physiologic grounds and supported by experimental and clinical data. This concept depicts shock as a defect in effective tissue perfusion, related to a decrease in cardiac output and organ blood flow and an increase in peripheral resistance. Restoration of cardiac output and organ blood flow by maintenance of effective circulating blood volume (central venous pressure, $10 \mathrm{~cm} . \mathrm{H}_{2} \mathrm{O}$, blood volume, $80 \mathrm{ml} . / \mathrm{kg}$.) in association with digitalization when indicated will be effective in most patients in shock. In the remaining patients in which resistance in the cutaneous and visceral microcirculation remains elevated (pale, cool extremities and reduced urinary output), increased blood How can be promoted in these areas by use of drugs which decrease vasoconstriction by blocking alpha-receptors (phenoxybenzamine, phentolamine, chlorpromazine) or decrease resistance to flow by yet unknown means (massive doses of glucocorticosteroids) or decrease resistance by beta-receptor stimulation (isoproterenol) and consequent dilatation of the microcirculation of the muscles, while also stimulating the same receptors in the heart to increase the force and rate of cardiac contraction. In view of the dismal results obtained by vasopressors, alpha-receptor stimulators such as Levarterenol and Aramine, the use of these substances should be abandoned as the only form of treatment in shock.

\section{RÉSUMÉ}

On a proposé un concept unitaire du choc basé sur des données physiologiques théoriques et on l'a confirmé par des résultats expérimentaux et chimiques. Ce concept décrit le choc comme une lacune, une faille, dans la perfusion efficace 
des tissus. Cette lacune s'accompagne d'un diminution du débit cardiaque et de la circulation de l'organe et d'une augmentation de la résistance périphérique. La restoration du débit cardiaque et de la circulation de l'organe en maintenant un volume sanguin circulant efficace (pression veineuse centrale: $10 \mathrm{~cm}$. d' $\mathrm{H}_{2} \mathrm{O}$, volume sanguin: $80 \mathrm{ml} / \mathrm{kg}$.) et en y ajoutant la digitalisation lorsque nécessaire sera efficace chez la plupart des malades en choc. Chez les autres malades, chez qui la résistance dans la microcirculation cutanée et viscérale demeure élevée (paleur, extrémités froides et débit urinaire diminué) il est possible d'augmenter la circulation dans ces régions en utilisant des médicaments qui diminuent la vasoconstriction en bloquant les récepteurs alpha (la phénoxybenzamine, la phentolamine, la chlorpromazine) ou qui diminuent la réstistance à la circulation par des moyens encore inconnus (doses massives de glucocorticostérö̈des) ou qui diminuent la résistance en stimulant le récepteur bêta (isoproterenol) et entraînent une dilatation de la microcirculation dans les muscles tout en stimulant également les mêmes récepteurs dans le cœur pour augmenter la force et la vitesse de la contraction cardiaque. A cause des résultats aléatoires obtenus avec les vasopresseurs, stimulateurs des récepteurs alpha, tels le levarterenol et l'aramine, l'usage de ces substances devrait être mis de côté comme la seule façon de traiter le choc.

\section{REFERENCES}

1. Binder, M. J.; Ryan, J. A.; Jr., Marcus, S.; Mugler, F., Jr.; Strange, D.; \& Agress, C. M. Evaluation of Therapy in Shock following Acute Myocardial Infarction. Am. J. Med. 18: 622 (1955).

2. Bloch, J. H.; Pierce, C. H.; Manax, W. G.; \& Lillehei, R. C. Treatment of Experimental Cardiogenic Shock. Surgery. 58: 197 (1965).

3. Rosenberg, J. C.; Lillehei, R. C.; Longerbeam, J.; \& Zmmerman, B. Studies on Hemorrhagic and Endotoxin Shock in Relation to Vasomotor Changes and Endogenous Circulating Epinephrine, Norepinephrine and Serotonin. Ann. Surg, 154:611 (1961).

4. Lillehei, R. C.; Longerbeam, J. K.; Bloch, J. H.; Manax, W. G. Hemodynamic Changes in Endotoxin Shock. Reprinted from Shock and Hypotension, by Grune and Stratton, 1965 , p. 442.

5. Bloch, J. H.; Dietzman, R. H.; Pierce, C. H.; \& Lillehei, R. C. Theories of the Production of Shock: A Review of the Relevance to Clinical Practice. Brit. J. Anaesth. 38: 234 ( 1966).

6. Bloch, J. H.; Pierce, C. H.; \& Lillener, R. C. Adrenergic Blocking Agents in the Treatment of Shock. Reprinted from Ann. Rev. Med. 17: 483 (1966).

7. Rosenthal, M. E. \& Dipalma, J. R. Norepinephrine Storage and Acute Tolerance. Arch. internat. pharmacodyn. 146: 529 (1963). 